\title{
UTILIZATION OF DIGITAL CONTENT OF LEARNING SOURCES CENTER (LRC) IN SCHOOL OF PASS RECEIVER ASSISTANCE DEVICES OF PSB
}

\author{
Eni Susilawati, Ai Sri Nurhayati, Kusnandar \\ Pusdatin Kemendikbud, JI RE Martadinata Km 5,5 Ciputat, Tangsel \\ e-mail: \\ ensiwa15@gmail.com, sri.nurhayati@kemdikbud.go.id, \\ kusnandar@kemdikbud.go.id
}

\begin{abstract}
Learning Resources Center (LRC) in schools provides a wide selection of learning resources to support learning activities and encourage effective learning so as to achieve learning goals. LRC assistance has been provided from 2016 to 2019, so a research is needed to determine its utilization in schools. This research aims to determine the description of the utilization of ICT tools to support the learning process, as well as obstacles encountered, and recommendations for solution in use of ICT tools and content of LRC for learning in schools. Research uses evaluation research using CIPP (context, input, process and product). The samples are headmasters, teachers, and education staff in schools receiving PSB assistance from Data Center and Information Technology (Pusdatin) Ministry of Education and Culture Education Center in the 2016 to 2019 which is spread in various regions of Indonesi. Data collection using online questionnaires, interviews, limited observation, and documentation. The results showed that:1) The forms of utilizing PSB digital content in schools vary including: most teachers present in front of the class using projectors with the lecture method and some have integrated with other learning models, forms of use are used as independent learning resources for students both individually and in groups or on scheduled; 2) In general the availability of inovative teachers is quite adequate, as many as $31 \%$ of schools have more than 5 teachers who are able to make independent digital learning materials and $53 \%$ of schools have less than 5 teachers who are able to make independent digital learning materials; 3) Some recommendations in an effort to improve the quality of utilizing PSB digital content and PSB assistance tools, namely the need: increasing the availability of ICT infrastructure, improving the quality of HR management of PSB, increasing the quality of applications and quantity of PSB digital content, and improving the quality of policy support.
\end{abstract}

Keywords: learning resources, digital conent, ICT utilization, innovative instruction 


\title{
PEMANFAATAN KONTEN DIGITAL PUSAT SUMBER BELAJAR (PSB) PADA SEKOLAH RINTISAN PENERIMA BANTUAN PERANGKAT PSB
}

\author{
Eni Susilawati, Ai Sri Nurhayati, Kusnandar \\ Pusdatin Kemendikbud, JI RE Martadinata Km 5,5 Ciputat, Tangsel \\ e-mail: \\ ensiwa15@gmail.com, sri.nurhayati@kemdikbud.go.id, \\ kusnandar@kemdikbud.go.id
}

\begin{abstract}
Abstrak: Pusat Sumber Belajar (PSB) di sekolah menyediakan berbagai macam pilihan sumber belajar untuk mendukung kegiatan pembelajaran dan mendorong cara belajar yang efektif sehingga dapat mencapai tujuan pembelajaran. Bantuan PSB telah diberikan sejak tahun 2016 sampai dengan tahun 2019, sehingga perlu dilakukan kajian untuk mengetahui pemanfaatannya di sekolah. Penelitian ini bertujuan untuk mengetahui gambaran pemanfaatan bantuan perangkat TIK untuk menunjang proses pembelajaran, serta kendala yang dihadapi, dan rekomendasi solusi dalam pemanfaatan bantuan perangkat TIK dan konten PSB untuk pembelajaran di sekolah penerima bantuan PSB. Penelitian menggunakan penelitian evaluasi dengan menggunakan model CIPP (context, input, process dan product). Sampel adalah kepala sekolah, guru-guru dan tenaga kependidikan pada sekolah penerima bantuan perangkat PSB dari Pusdatin Kemendikbud Tahun $2016 \mathrm{~s} / \mathrm{d}$. Tahun 2019 yang tersebar di berbagai wilayah Indonesia. Pengumpulan data menggunakan kuesioner online, wawancara, observasi terbatas, dan dokumentasi. Hasil penelitian menunjukkan bahwa: 1) Bentuk pemanfaatan bantuan konten digital PSB di sekolah beragam diantaranya: Sebagian besar guru menyajikan di depan kelas menggunakan projector dengan metode ceramah dan ada yang sudah mengintegrasikan dengan model pembelajaran lainnya, bentuk pemanfaatan digunakan sebagai sumber belajar mandiri bagi siswa baik individu maupun kelompok atau secara terjadwal; 2) Pada umumnya ketersediaan guru penggerak cukup memadai, sebanyak 31\% sekolah memiliki lebih dari 5 orang guru yang mampu membuat bahan belajar digital mandiri dan $53 \%$ sekolah memiliki kurang dari 5 orang guru yang mampu membuat bahan belajar digital mandiri; 3) Beberapa rekomendasi dalam upaya peningkatan kualitas pemanfaatan konten digital PSB dan perangkat bantuan PSB yaitu perlunya: peningkatan ketersediaan sarana prasarana TIK, peningkatan kualitas SDM pengelola PSB, peningkatan kualitas aplikasi dan kuantitas konten digital PSB, serta peningkatan kualitas dukungan kebijakan.
\end{abstract}

Kata kunci: sumber belajar, konten digital, pemanfaatan TIK, pembelajaran inovatif 


\section{PENDAHULUAN}

Salah satu berkah dari perkembangan teknologi informasi dan komunikasi (TIK) adalah melimpahnya konten sumber belajar digital yang semakin banyak dan beragam. Sumber belajar tersebut tentu saja perlu dikelola dengan baik, sehingga dapat dimanfaatkan secara optimal. Pengelolaan dan pemanfaatan sumber belajar di sekolah dapat dikelola secara sistematis dan terpusat melalui Pusat Sumber Belajar (PSB). Pada hakikatnya, PSB merupakan suatu tempat atau unit layanan di sekolah yang di dalamnya terdapat aktivitas terorganisir, dipimpin oleh seorang ketua PSB dengan didukung oleh segenap staf, peralatan produksi, dan dana memadai, yang menjalankan program secara aktif dalam desain, pengembangan, pemanfaatan, pengelolaan, dan evaluasi sumber belajar, untuk memfasilitasi dan meningkatkan hasil belajar dan pembelajaran, baik secara individual maupun kelompok, serta menyediakan layanan pengembangan dan perencanaan yang terkait dengan kurikulum dan pembelajaran.

Pusat Data dan Teknologi Informasi Pendidikan dan Kebudayaan, Kementerian Pendidikan dan Kebudayaan yang salah satu tugas dan fungsinya memberikan layanan fasilitasi pengembangan dan pendayagunaan TIK untuk pendidikan dan kebudayaan kepada masyarakat telah memberikan bantuan perangkat TIK untuk mendukung piloting atau rintisan pemanfaatan Pusat Sumber Belajar (PSB) berbasis TIK di sekolah. Jumlah sekolah yang telah mendapat bantuan perangkat TIK dan konten digital hypermedia pembelajaran dalam bentuk konten Rumah Belajar offline sejak tahun 2016 s.d 2019 sebanyak 62 sekolah. Bantuan perangkat Pusat Sumber Belajar (PSB) berupa empat buah laptop, sebuah LCD proyektor, sebuah akses point, dan sebuah PC server yang sudah terisi dengan konten-konten digital PSB. Bantuan tersebut diharapkan dapat mendorong sekolah dalam meningkatkan kualitas pembelajaran dengan mengoptimalkan pengelolaan, pemanfaatan, dan pendayagunaan konten PSB di sekolah sehingga berhasil meningkatkan minat belajar dan meningkatkan hasil belajar siswa. Agar pemberian bantuan perangkat TIK dan konten digital PSB dapat dimanfaatkan sesuai dengan tujuannya, maka telah dilakukan pendampingan pemanfaatan perangkat TIK dan konten digital PSB secara berkala sejak tahun 2019 yang dilakukan secara jarak jauh dan online, yaitu melalui grup whatsapp dan video konferensi (vicon). Hal tersebut didukung oleh hasil penelitian Kusnandar (2018) yang merekomendasikan adanya pendampingan jarak jauh untuk sekolah penerima bantuan TIK dengan memanfaatkan TIK itu sendiri. Oleh karena itu untuk melihat sejauh mana pemanfaatan konten digital PSB yang memanfaatkan bantuan perangkat TIK di sekolah rintisan penerima bantuan PSB dan kendalanya, serta menyusun rekomendasi upaya peningkatan kualitas pemanfaataan konten digital PSB maka perlu dilakukan penelitian.

Tujuan penelitian adalah untuk mengetahui gambaran pemanfaatan konten digital PSB yang memanfaatkan bantuan perangkat TIK dalam rangka perintisan pemanfaatan PSB digital untuk menunjang proses pembelajaran. Serta gabaran mengenai kendala yang dihadapi, dan rekomendasi solusi dalam pemanfaatan konten PSB digital untuk pembelajaran di sekolah rintisan penerima bantuan PSB. 
Permasalahan dalam tulisan ini dapat dirumuskan sebagai berikut:

$\checkmark$ Bagaimana gambaran pemanfaatan konten digital PSB yang memanfaatkan bantuan perangkat TIK dalam rangka perintisan pemanfaatan PSB digital untuk menunjang proses pembelajaran serta kendala yang dihadapi?

$\checkmark$ Seberapa banyak guru yang aktif (guru penggerak) dalam memanfaatkan bantuan perangkat TIK untuk pembelajaran?

$\checkmark$ Rekomendasi apa saja yang dapat disampaikan untuk peningkatan kualitas pemanfaatan konten PSB digital untuk menunjang proses pembelajaran?

Konten digital PSB digital berisi konten-konten Sumber Belajar dari portal Rumah Belajar (versi offline), konten SLIM (Senayan Library Management Systems) offline berupa buku digital dan karya bahasa dan sastra yang dapat diakses dengan menggunakan jaringan LAN dari wifi router. Rumah Belajar merupakan portal pembelajaran yang telah dikembangkan oleh Pusat Data dan Teknologi Informasi (Pusdatin) yang merupakan perubahan dari Pusat Teknologi Informasi dan Komunikasi (Pustekkom) Kemendikbud sejak tahun 2003 dengan nama e-dukasi.net, dan kemudian pada tahun 2011 diganti namanya menjadi Rumah Belajar, sebagai platform pembelajaran digital resmi Kemendikbud. Portal Rumah Belajar dapat diakses secara online melalui www.belajar.kemdikbud.go.id. Bisa juga melalui android dengan menginstall aplikasi Rumah Belajar. Portal Rumah Belajar menyediakan berbagai fitur dan konten pembelajaran menarik, yang dapat dimanfaatkan oleh guru, siswa maupun masyarakat umum secara gratis. Fitur-fitur Rumah Belajar meliputi: Sumber Belajar, Kelas digital, Laboratorium Maya, Bank Soal, Peta Budaya, Buku Sekolah Elektromagnetik (BSE), Wahana Jelajah Angkasa dan PKB (Pengembangan Keprofesian Berkelanjutan).

Pemanfaatan Rumah Belajar dapat dijadikan sebagai salah satu solusi belajar secara daring di rumah bagi siswa selama pandemi covid-19 di Indonesia. Sesuai dengan pendapat Ayunda (2020), menyatakan Rumah Belajar Kementerian Pendidikan dan Kebudayaan (Kemendikbud) merupakan salah satu portal pembelajaran daring yang menyajikan materi pelajaran secara interaktif pada masa pandemi covid-19. Hasil Penelitian Martiningsih (2013), menyebutkan bahwa penggunaan konten Rumah Belajar terbukti dapat meningkatkan kualitas pembelajaran dan peningkatan prestasi belajar peserta didik Matematika tentang materi irisan dan gabungan dua himpunan himpunan di kelas VII A SMP Muhammadiyah 1 Surabaya tahun ajaran 2012/2013. Sehingga dalam dalam web PSB online didalamnya diintegrasikan konten Rumah Belajar, dan untuk bantuan PSB diberikan 1 eksternal hardisk yang berisi konten digital PSB yang dapat dipergunakan secara offline. Diharapkan dengan mengintegrasikan konten Rumah Belajar sebagai bagian dari konten digital PSB, dapat meningkatkan kualitas proses dan hasil belajar siswa. Hasil penelitian Filoza, $d k k$ (2019) menyatakan bahwa penggunaan portal rumah belajar berpengaruh secara signifikan dalam meningkatkan kemampuan berpikir kreatif siswa.

\section{METODE}

Penelitian ini merupakan penelitian evaluasi dengan menggunakan model CIPP. Stuffleabem dan Coryn (2014) menyatakan model evaluasi CIPP merupakan 
model yang mengevaluasi secara sistematis dan komprehensif terkait context, input, process, product, suatu program. Penelitian ini merupakan studi kasus pada sekolah-sekolah rintisan penerima bantuan perangkat PSB dari Pusdatin. Sampel penelitian adalah kepala sekolah, guru-guru dan tenaga kependidikan pada sekolah rintisan penerima bantuan perangkat PSB dari Pusdatin Kemendikbud Tahun 2016 s/d Tahun 2019 yang tersebar di berbagai wilayah Indonesia.

Waktu penelitian ini selama dua bulan yaitu mulai tanggal 17 Februari 2020 sampai dengan 5 April 2020. Teknik pengumpulan data yang digunakan adalah kuesioner online, wawancara, observasi terbatas, dan dokumentasi. Kuesioner online menggunakan aplikasi https://formulir.kemdikbud.go.id milik Kemendikbud. Analisis data dalam penelitian ini menggunakan model analisis interaktif yang meliputi: Pengumpulan data, rediksi data, penyajian data dan penarikan kesimpulan yang dilakukan dalam bentuk interaksi dengan proses pengumpulan data sebagai suatu proses siklus. Pengecekan keabsahan data yang didapatkan menggunakan triangulasi, dengan mengecek kebenaran data melalui wawancara secara online (video conference) menggunakan aplikasi webex meeting Pusdatin.

\section{HASIL DAN PEMBAHASAN}

Salah satu dampak perkembangan TIK adalah adanya tuntutan yang mengarah pada pengintegrasian Teknologi Informasi dan Komunikasi (TIK) dalam pembelajaran, sehingga sumber-sumber belajar pun mulai berbasis pada TIK. Penyelenggaraan PSB berkembang atas dasar tuntutan adanya suatu unit yang memfasilitasi peningkatan keterampilan belajar bagi peserta didik dan keterampilan membelajarkan bagi pendidik berbasis teknologi, penyelenggaraan pembelajaran online maupun blended, dan penggunaan TIK untuk mendukung proses belajar dan pembelajaran yang lebih aktif, inovatif, kreatif, efektif, dan menyenangkan. Dari data hasil penelitian, pada umumnya penyelenggaraan Pusat Sumber Belajar (PSB) di sekolah rintisan penerima bantuan perangkatTIK PSB tahun 2016-2019 berjalan cukup baik. Salah satu diantaranya terkait pemanfaatan konten PSB digital disekolahnya masing-masing. Sebagai sekolah yang memiliki PSB, pengelolaan pemanfaatan konten digital PSB ini menjadi hal yang penting, terutama untuk mendukung penerapan pembelajaran bagi siswa generasi milenial (generasi Z) saat ini, yang sangat dipengaruhi oleh perkembangan TIK dan kondisi masingmasing sekolah. Menurut Absher dan Amidjaya (2008) bahwa generasi millennial itu merupakan generasi yang lahirnya berkisar antara 1982 sampai dengan 2002. Generasi dalam era millennial ini biasa disebut generation Z, ditandai dengan meningkatnya penggunaan alat komunikasi, media dan teknologi informasi yang digunakan. Misalnya: Smartphone, internet, email, SMS, IM, MP3 Player, HP, Youtube, dan lain sebagainya.

Koleksi konten digital PSB menyediakan beragam media pembelajaran berbasis digital mulai dari jenjang PAUD hingga jenjang SMK dan umum. Koleksi media digital tersebut dapat diakses secara online melalui web PSB, atau dapat diakses secara offline melalui PSB digital yang dikemas dalam sebuah ekternal hardisk yang merupakan salah satu perangkat bantuan pada beberapa sekolah terpilih untuk TIK untuk mendukung piloting atau rintisan pemanfaatan Pusat Sumber Belajar (PSB) berbasis TIK. Koleksi konten digital PSB offline tersedia 
dalam berbagai bentuk media pembelajaran yaitu teks, audio, video, multimedia, buku elekronik dsb yang dikategorikan ke dalam jenjang pendidikan PAUD, SD, SMP, SMA, dan SMK. Konten tersebut bersumber darii konten web Rumah Beajar yang telah diunduh dan disimpan dalam media penyimpanan, sehingga dapat dimanfaatkan secara offline jika tidak memiliki jaringan internet. Pemanfaatan Rumah Belajar dapat secara online maupun offline. Hasil penelitian Susilawati (2019), penerapan model pembelajaran yang memanfaatkan rumah belajar dapat memilih rumah belajar online dan offline sesuai dengan kondisi sarana prasarana TIK yang dimiliki sekolah.

\section{Gambaran Pemanfaatan Konten Digital PSB}

Konten digital PSB yang berupa sumber belajar digital baik yang tersedia pada Rumah Belajar online maupun offline, disajikan dalam beragam bentuk konten media pembelajaran. Menurut data responden, trend pemilihan jenis konten yang dipilih guru dan siswa, hampir sama. Keduanya dominan memilih konten jenis video, seperti yang tergambar dalam grafik berikut:

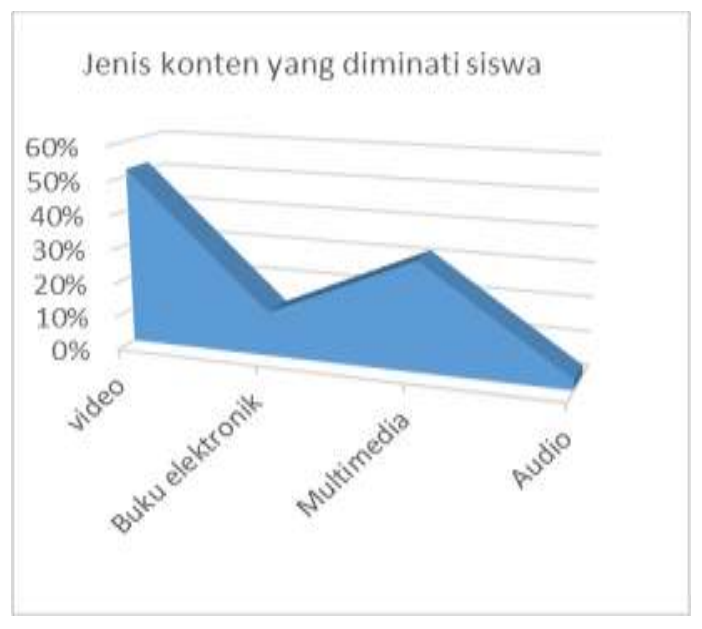

Gambar 1. Grafik format konten PSB yang siswa

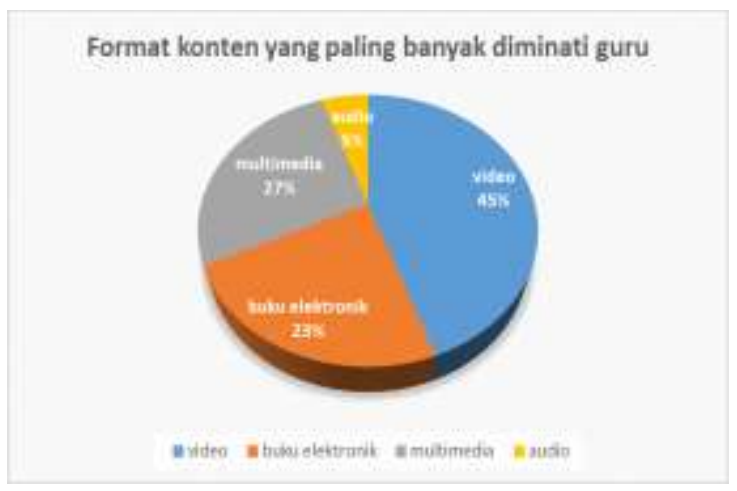

Gambar 2. Grafik format konten PSB yang diminati guru 
Konten digital dalam bentuk video terbukti paling banyak diminati karena merupakan salah satu konten digital PSB yang paling menarik bagi guru. Pemanfaatan sumber belajar digital PSB berupa konten video tersebut juga sesuai dengan trend konten yang disukai siswa yang merupakan generasi $Z$ saat ini, yaitu konten digital video. Hasil penelitian Anwas, dkk (2018) bahwa konten pembelajaran dalam bentuk video, animasi, dan multimedia interaktif lebih menarik pada generasi milenial. Konten video dalam aplikasi Rumah belajar merupakan salah satu konten yang dominan disukai siswa generasi milenial. Dengan konten video rumah belajar, pembelajaran lebih mudah dipahami oleh siswa. Pendapat tersebut juga didukung oleh Hevria (2019) menyatakan bahwa model contructivist learning dengan menggunakan video di Portal Rumah Belajar dapat mendukung pencapaian hasil belajar siswa. Dengan konten digital video, siswa tidak hanya melihat, mendengar, tetapi lebih dapat memahami secara visual sebuah obyek yang abstrak. Siswa menjadi lebih kreatif dan termotivasi dalam berpikir tingkat tinggi.

Selain dari sisi pemilihan jenis konten, pemanfaatan konten digital PSB juga dapat dikaji dari sisi bentuk pemanfaatannya dalam pembelajaran, terutama oleh guru sebagai fasilitator pembelajaran. Hasil evaluasi menunjukkan bahwa bentuk pemanfaatan Konten digital PSB tersebut sangat beragam, tiap sekolah PSB memiliki pola pemanfaatan yang berbeda, seperti yang terlihat dalam diagram berikut:

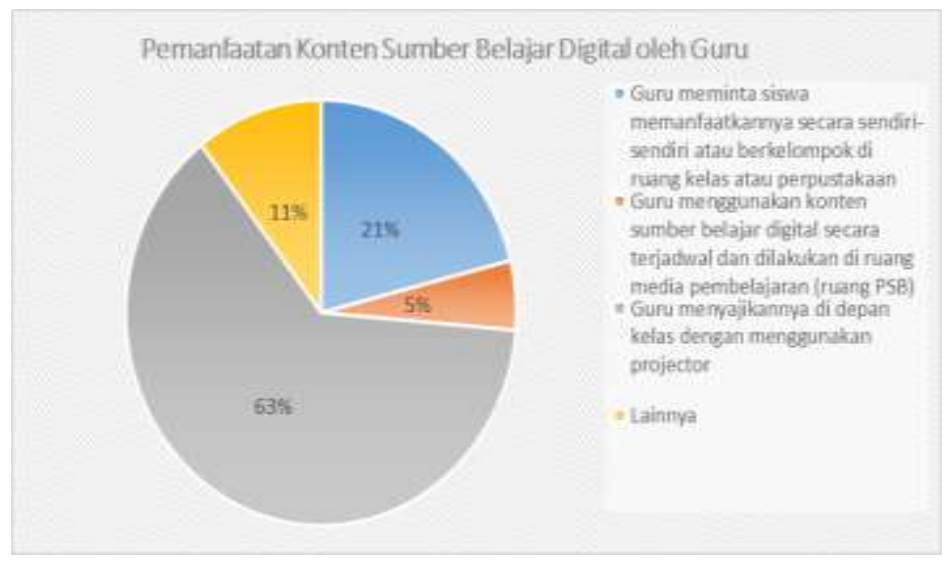

Gambar 3. Grafik pemanfaatan konten digital PSB

Dari data penelitian dengan resonden kepala sekolah menunjukkan bahwa mayoritas guru $(63 \%)$ menyajikan konten digital pembelajaran di depan kelas dengan menggunakan $L C D$ projector. Sebagian guru $(21 \%)$ memanfaatkan Konten digital PSB sebagai sumber belajar mandiri bagi siswa. Siswa ditugaskan secara sendiri-sendiri ataupun berkelompok memanfaatkan konten digital sumber belajar di ruang kelas maupun perpustakaan. Sebagian yang lain yaitu sebanyak $11 \%$ guru memanfaatkan Konten digital PSB secara terjadwal dan dilakukan di ruang PSB di masing-masing sekolah. 
Data di atas juga relevan dengan data hasil responden dari guru yang menyatakan bahwa guru paling banyak memanfaatkan konten digital PSB dengan cara menyajikan dengan metode ceramah di depan kelas menggunakan LCD projector, seperti yang dijelaskan dalam diagram pada Gambar 4.

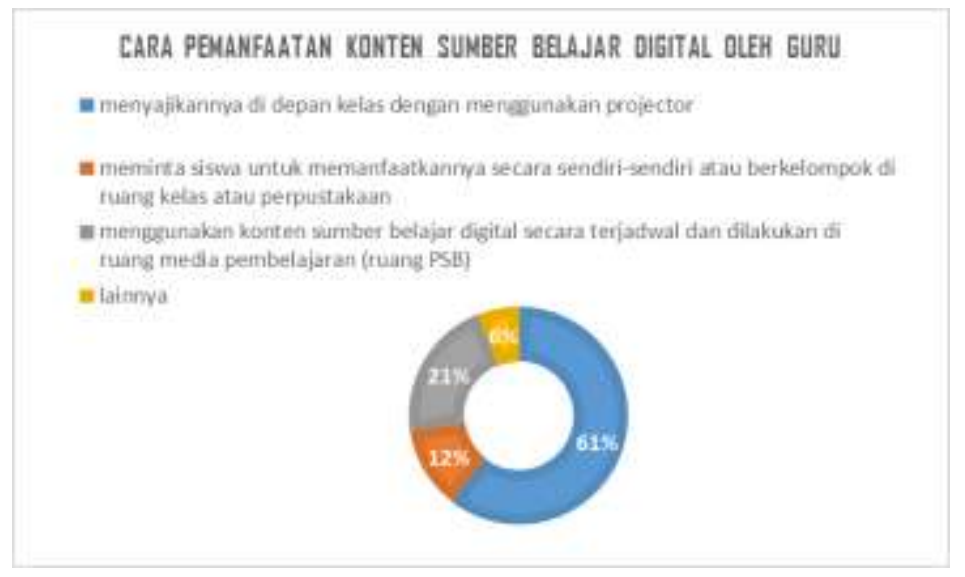

Gambar 4. Grafik cara pemanfaatan konten PSB digital

Keberagaman cara pemanfaatan Konten digital PSB di sekolah PSB ini sangat dipengaruhi oleh ketersediaan sarpras masing-masing sekolah. Karena salah satu perangkat bantuan berupa $L C D$ Projector, maka guru merasa paling mudah memanfaatkan Konten digital PSB dengan menggunakan LCD Projector yang dimilik sekolah tersebut. Dalam hal ini sebaiknya perlu ada pelatihan modelmodel pembelajaran inovatif bagi guru, sehingga bentuk pemanfaatan Konten digital PSB bisa dipadukan dengan berbagai model pembelajarn inovatif, sehingga menjadi lebih menarik dan bervariasi. Pemanfaatan Konten digital PSB dalam pembelajaran dapat dilakukan di dalam kelas maupun di luar kelas. Misalnya saat memadukan pemanfaatan sumber belajar digital PSB dengan penerapan model flipped classroom, maka sumber belajar digital tersebut dapat dipelajari secara mandiri/kelompok siswa di rumah. Begitu juga saat memadukan pemanfaatan sumber belajar digital PSB dengan penerapan model Discovery-inquiry, maka sumber belajar digital tersebut dapat dijadikan bagian dari aneka sumber belajar pada sintak collecting data. Sehingga siswa bisa mempelajari konten tersebut secara bersamaan di kelas, perpustakaan, laboratorium ataupun di luar kelas sesuai dengan skenario pembelajaran yang telah disusun guru berdasarkan tahapan model pembelajaran discovery-inquiry. Pengintegrasian model pembelajaran discovery-inquiry dalam pembelajaran menjadikan pembelajaran menjadi lebih menarik bagi siswa dibanding jika hanya menggunakan metode ceramah (konvensional). Hasil penelitian Asy'ari dan Zulkarnain (2019) bahwa siswa yang diberi perlakuan model pembelajaran berbasis TIK menggunakan metode discovery learning lebih baik dari hasil belajar siswa yang diberi model pembelajaran konvensional. Hal karena model pembelajaran berbasis TIK menggunakan metode discovery learning mendorong siswa untuk aktif dalam pembelajaran, dimana siswa dituntut untuk aktif dalam belajar materi bangun ruang dengan pembelajaran berbasis computer yang inovatif. 
Bentuk pemanfaatan konten digital PSB oleh guru ini, dipengaruhi beberapa hal, diantaranya: Belum semua guru mahir menggunakan TIK, masih kurangnya keterampilan pedagogis guru terutama terkait penerapan model-model pembelajaran inovatif, dan keterbatasan sarana prasarana PSB serta adanya guru yang belum memahami cara pemanfaatan konten PSB karena sekolah nya belum pernah mendapatkan Bimtek PSB. Oleh karena itu kedepannya perlu diselenggarakan bimtek pemanfaatan konten PSB bagi yang belum, pelatihan peningkatan kompetensi TIK dan juga model-model pembelajarn inovatif bagi guru sekolah PSB. Bimtek dapat dilakukan secara daring maupun tatap muka. Perlunya pelatihan ini untuk mendukung penyelenggaraan fungsi PSB. Hasil penelitian Rahmadi (2017) menyatakan bahwa fungsi PSB saat ini sebaiknya lebih diarahkan pada: (1) Pengembangan sistem pembelajaran berbasis teknologi, berupa pembelajaran online maupun blended; (2) Pelayanan terkait sumber belajar kepada pendidik dan peserta didik; (3) Penyelenggaraan berbagai pelatihan atau kursus yang dapat diikuti secara fleksibel dan sesuai dengan kebutuhan serta gaya belajar; (4) Administrasi PSB secara online.

\section{Kondisi Bantuan perangkat TIK PSB dan pemanfaatannya}

Data mengenai kondisi perangkat bantuan PSB, kami gali dari hasil instrumen yang telah diisi oleh pengelola TIK di Sekolah penerima bantuan perangkat PSB. Bantuan perangkat PSB yang telah diterima para responden tersebut terdiri dari laptop, server, wifi router, LCD projector dan eksternal hardisk yang berisi konten rumah belajar offline. Dari kelima jenis perangkat bantuan tersebut, kondisi fisik software maupun hardware-nya masing-masing berfungsi dengan baik seperti yang diperlihatkan pada Gambar 5 .

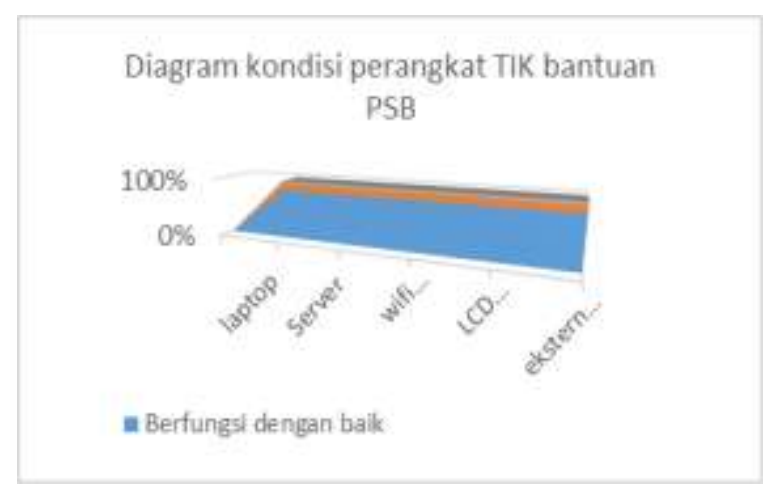

Gambar 5. Grafik kondisi perangkat TIK bantuan

Berdasarkan data responden di atas, jika dilihat prosentansenya maka kondisi perangkat bantuan tersebut dapat disajikan dalam grafik pada Gambar 6 . 


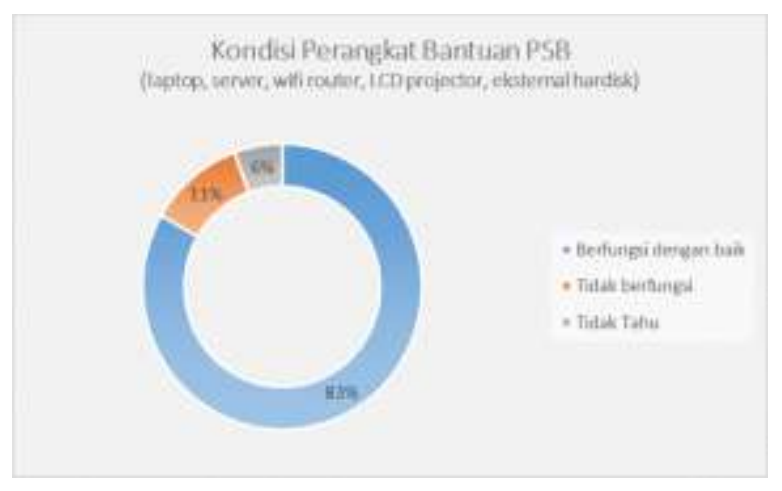

Gambar 6. Grafik kondisi perangkat bantuan PSB

Kondisi perangkat TIK baik software maupun hardware bantuan PSB dari Pusdatin, mayoritas masih berfungsi dengan baik. Hal tersebut terlihat juga dari data guru yang telah memanfaatkan konten digital PSB, diantaranya dengan menggunakan laptop dan LCD Projector untuk ditampilkan di kelas. Sebagian yang lain ada yang pemanfaatannya sebagai sumber belajar mandiri bagi siswa ataupun kelompok siswa yang mengakses di perpustakaan maupun ruang khusus PSB, karena perangkat PSB diletakkan di perpustakaan dan di ruang khusus PSB. Melihat kondisi perangkat bantuan PSB tersebut, sebaiknya untuk perangkat yang sudah tidak berfungsi segera ditindaklanjuti kendalanya, jika rusak segera diperbaiki dan sebagainya. Bagi responden sekolah yang menjawab tidak tahu, ini merupakan responden sekolah yang belum pernah mendapat Bimtek pemanfaatan perangkat bantuan PSB, sehingga perlu ditindaklanjuti untuk dilakukan sosialisasi atau bimtek bagi sekolah tersebut.

Kulaitas pemanfaatan konten PSB sangat dipengaruhi oleh keberadaan guru penggerak di sekolah tersebut. Gambaran jumlah guru yang aktif (guru penggerak) dalam memanfaatkan bantuan perangkat TIK untuk pembelajaran inisiatif pembelajaran Pada sekolah PSB yang telah memiliki dan memanfaatkan konten digital PSB, idealnya memiliki satu atau dua orang guru inovatif yang berinisiatif menjadi penggerak bagi rekan sejawatnya. Terkait hal ini, hasil penelitian menunjukkan bawa terdapat $84 \%$ sekolah yang telah memiliki guru penggerak. Sedangkan 16\% lainnya tidak ada guru yang menjadi penggerak, seperti yang disajikan dalam diagram pada Gambar 7 .

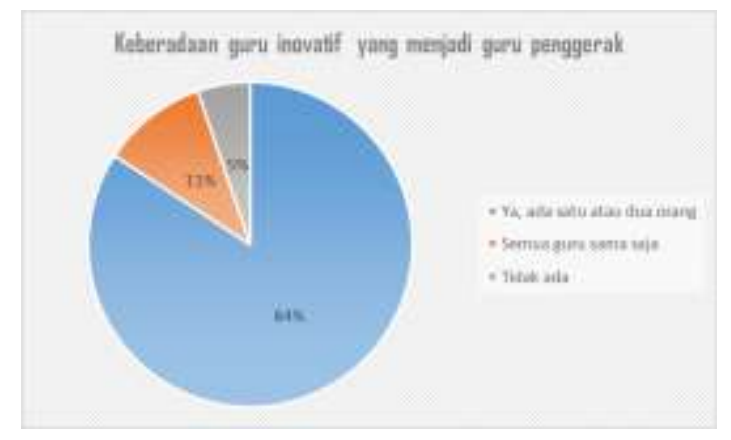

Gambar 7. Grafik keberadaan guru penggerak di sekolah PSB 
Selain sebagai penggerak dalam menerapkan pembelajaran inovatif yang memanfaatkan konten digital PSB, guru inovatif tersebut juga tidak sedikit yang sudah mampu mengembangkan sendiri konten digital.

Dari hasil tanggapan responden, diperoleh data bahwa terdapat $31 \%$ sekolah yang memiliki guru lebih dari 5 orang guru yang mampu membuat konten bahan belajar digital mandiri, 53\% sekolah memiliki kurang dari 5 guru yang mampu mebuat bahan belajar digital mandiri. Sedangkan 16\% sekolah tidak memiliki guru yang mampu membuat konten pembelajaran mandiri.

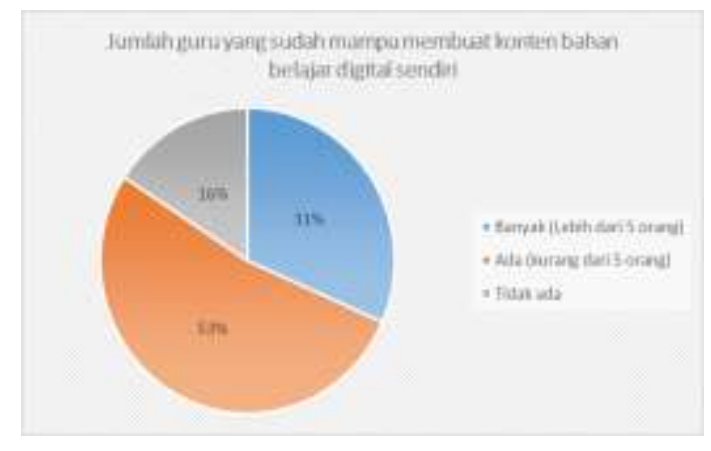

Gambar 8. Grafik jumlah guru PSB yang mampu membuat konten digital

Adanya guru penggerak di sekolah PSB akan sangat berpengaruh terhadap kualitas pengelolaan PSB di masing-masing sekolah, khususnya dalam mewujudkan inovasi pembelajaran. Salah satu inovasi pembelajaran di sekolah PSB adalah pembelajaran dengan memanfaatkan konten digital PSB. Untuk itu guru penggerak di sekolah PSB harus terus menerus belajar dan meningkatkan pengetahuan serta keterampilannya agar dapat menciptakan hal-hal baru guna peningkatan mutu pembelajaran di sekolahnya. Adapun bentuk inovasi pembelajaran yang memanfaatkan Konten PSB digital, diantaranya: 1) Adanya pembelajaran di sekolah yang dapat mengoptimalkan integrasi TIK dalam proses belajar siswa, sesuai dengan ketersediaan sarana prasarana TIK yang dimiliki sekolah dan siswa, 2) Terlaksananya pembelajaran yang memanfaatkan kontenkonten PSB sesuai kebutuhan belajar siswa, yang dipadukan dengan penerapan model pembelajaran yang variatif yang berpusat pada siswa untuk mewujudkan joyfull learning, 3) Meningkatnya professionalism guru dalam mengkreasikan pemanfaatan konten PSB dalam pembelajaran sesuai dengan tuntutan kurikulum dan kontekstual dengan kearifan/permasalahan lokal masing-masing sekolah PSB, 4) Meningkatya keaktifan partisipasi guru dalam mendukung terwujudnya inovasi dalam pembelajaran, misalnya kemampuan dalam mengembangkan media pembelajaran yang up to date.

Untuk meningkatkan jumlah guru penggerak di masing-masing sekolah PSB, dibutuhkan adanya dukungan dan komitmen manajemen sekolah dalam memberikan kelonggaran dan kesempatan bagi guru untuk berinovasi dan berkreasi dalam pembelajaran yang memanfaatkan konten digital PSB. Bagi sekolah yang belum memiliki guru penggerak, sebaiknya ada kebijakan sekolah untuk menugaskan beberapa guru mengikuti pelatihan kompetensi TIK guru 
termasuk diantara Bimtek daring PSB digital agar dapat memotivasi guru untuk berinovasi dalam pembelajaran.

Dari data responden menunjukkan bahwa pemanfaatan Konten digital PSB oleh guru disekolah PSB memiliki frekuensi yang beragam, seperti terlihat pada Gambar 9.

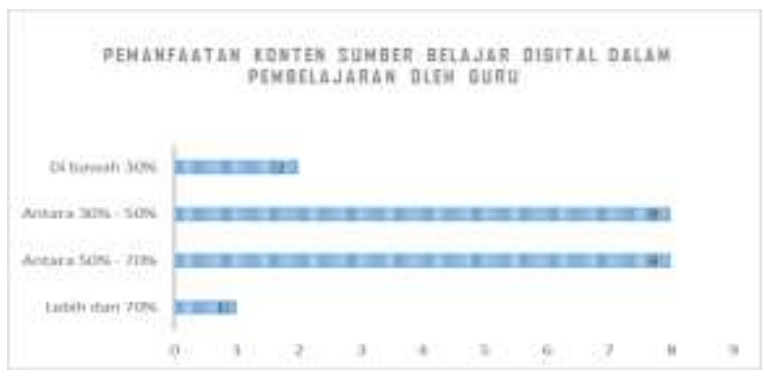

Gambar 9. Grafik frekuensi pemanfaatan konten digital PSB

Pemanfaatan Konten digital PSB oleh guru di sekolah PSB, selain pola pemanfaatannya yang beragam, juga terlihat frekuensi pemanfaatan konten yang berbeda oleh masing-masing guru, terutama untuk mendukung pembelajaran inovatif. Dari data responden terlihat bahwa 5\% sekolah memiliki lebih dari $70 \%$ guru yang telah memanfaatkan konten digital PSB dalam pembelajaran, 42\% sekolah memiliki 2/3 gurunya telah memanfaatkan konten digital PSB dalam pembelajaran, $42 \%$ sekolah guru memiliki $1 / 3$ gurunya telah memanfaatkan konten digital PSB dalam pembelajaran, dan sekitar $11 \%$ sekolah memiliki kurang dari $1 / 3$ gurunya yang telah memanfaatkan konten digital PSB dalam pembelajaran.

Hampir semua responden menyatakan telah memanfaatkan konten digital PSB dalam pembelajaran, hal tersebut berarti bahwa semua sekolah telah memahami manfaat dari konten digital PSB tersebut. Perbedaan frekuensi pemanfaatn konten PSB oleh guru seperti terlihat dalam bagan di atas, salah satunya dipengaruhi oleh motivasi guru. Guru yang mengetahui banyaknya manfaat konten digital dan mengetahui cara pemanfaatan konten digital PSB maka frekuensi pemanfaatannya cenderung lebih besar. Berikut beberapa manfaat konten digital PSB berdasarkan kondisi pemanfaatan di sekolah PSB oleh responden guru, meliputi: 1) Pembelajaran lebih bervariasi, lebih praktis dan ekonomis, serta mengikuti perkembangan teknologi, 2) Proses pembelajaran menjadi lebih interaktif, menarik dan menyenangkan, 3) Siswa menjadi lebih fokus, lebih semangat, antusias dan aktif dalam belajar, 4) Aneka sumber belajar menjadi lebih bervariasi, 5) Memperluas referensi konten pembelajaran, 6) Mempermudah siswa dalam belajar karna dapat diakses dari mana saja, 7) Mempermudah guru menjelaskan materi pembelajaran sulit yang bersifat abstrak 8) Mendorong guru menjadi lebih kreatif dalam pembelajaran, 9) Memudahkan guru dalam menyiapkan dan menyampaikan materi pelajaran, 10) Meningkatkan minat siswa untuk belajar hal baru sesuai dengan karakter generasi milenial. Mengingat banyaknya manfaat bantuan konten PSB digital tersebut, sebaiknya kuantitas bantuan konten PSB digital ditingkatkan, terutama kuantitas jumlah sekolah penerima bantuan konten digital PSB tersebut. 


\section{Kendala pemanfaatan konten digital PSB dan bantuan perangkat PSB dalam pembelajaran serta Rekomendasi solusi}

Pemanfaatan Konten digital PSB oleh guru, siswa dan sekolah di masingmasing sekolah PSB memiliki kendala yang berbeda-beda. Dari data responden, diperoleh identifikasi kendala dalam pemanfaatan Konten digital PSB meliputi: 1) Kendala terkait aspek ketersediaan sarana prasarana TIK yaitu adanya keterbatasan sarana prasarana TIK tidak sebanding dengan jumlah siswa, sehingga sedikit siswa yang dapat memanfaatkan, Ruang PSB yang terlalu panas karena tidak memiliki AC, dan kendala jaringan internet karena lokasi sekolah ada yang di pegunungan dan sebagainya. Dalam pembelajaran yang mengintegrasikan TIK termasuk diantaranya konten digital PSB membutuhkan dukungan ketersediaan sarpras TIK. Hal ini sesuai dengan hasil penelitian Nurabadi 2014) yang menyatakan bahwa ketersediaan perangkat $\mathrm{TI}$ (jaringan, perangkat keras, server, dan aplikasi) dapat meningkatkan mutu pembelajaran di FIP UM. Hal ini juga didukung oleh Antonius dalam Nurabadi (2014) yang menyatakan bahwa semua perangkat-perangkat kelengkapan sekolah dapat menunjang proses pembelajaran di sekolah. Hasil penelitian lainnya menyatakan bahwa terdapat pengaruh positif pemanfaatan TIK terhadap kinerja guru (Destiana, 2014)

Untuk mengatasi kendala ketersediaan sarpras TIK ini, ada beberapa upaya yang bisa direkomendasikan, yaitu: Perlu ditingkatkan kuantitas/jumlah ketersediaan sarpras TIK di sekolah PSB secara mandiri maupun melibatkan partisipasi masyarakat (stake holder, orangtua, komite sekolah dan sebagainya). Pelibatan masyarakat dan stake holder ini menjadi hal yang penting terutama bagi sekolah yang memiliki keterbatasan anggaran biaya. Upaya selanjutnya yaitu perlu adanya perbaikan bagi perangkat PSB yang sudah tidak berfungsi (rusak) secara mandiri ataupun dengan berkoordinasi pada pihak pemberi bantuan perangkat PSB. Dari hasil data statistik responden (Gambar 5) menunjukkan ada beberapa sekolah yang menyatakan perangkatnya tidak bisa berfungsi (rusak), sehingga perlu diperbaiki. Untuk kedepannya sebaiknya Pusdatin perlu meningkatkan upaya monitoring terhadap pemanfaatan perangkat bantuan dalam pembelajaran, sehingga dapat segera diatasi jika ada kendala rusak dan sebagainya. Upaya lain dalam mendukung pemanfaatan sarpras TIK dalam pengelolaan PSB adalah dengan melengkapi sarpras pendukung lainnya, misalnya ketersediaan $A C$, meningkatkan bandwith internet, keamanan fisik dan sebagainya.

Selanjutnya kendala pemanfaatan konten digital PSB dan bantuan perangkat TIK dalam pembelajaran terkait aspek SDM pengelola PSB meliputi: Kurangnya kemampuan TIK guru; Kurangnya penguasaan guru tentang cara penggunaan konten dan aplikasi PSB; Tidak tersedianya guru penggerak; Kurangnya minat dan motivasi guru dalam memanfaatkan perangkat dan konten digital PSB.

Dalam pengelolaan PSB termasuk diantaranya pemanfaatan perangkat dan konten digital PSB peranan SDM pengelola sangat menentukan. Beberapa upaya yang dapat direkomendasikan untuk mengatasi kendala tersebut, yaitu: Perlu ditingkatkan upaya sosialisasi tentang konsep dan pedoman pengelolaan PSB bagi guru, petugas perpustakaan dan laboratorium, serta pengelola TIK. Sosialisasi ini penting terutama bagi sekolah yang memiliki pengelola PSB yang sudah bergantiganti. 
Upaya lainnya yaitu dengan meningkatkan motivasi dan minat guru terhadap pemanfaatan konten digital PSB; Meningkatkan jumlah guru penggerak/inovatif di masing-masing sekolah PSB; Meningkatkan freuensi kegiatan atau forum para guru dapat berbagi pengetahuan (peer teaching) tentang pemanfaatkan Konten digital PSB atau TIK; Mengikutsertakan Bimtek PSB bagi sekolah yang belum mendapatkan Bimtek PSB; Meningkatkan keterampilan TIK bagi SDM pengelola PSB terutama terkaiat perawatan dan pemanfaatan perangkat PSB (hardware dan software); Meningkatkan keterampilan TIK dan paedagogis bagi guru di sekolah PSB sesuai dengan kebutuhan guru. Diharapkan dengan beberapa upaya di atas dapat mengatasi kendala pemanfaatan terkait SDM penyelenggara PSB, sekaligus dapat meningkatkan kualitas pemanfaatan bantuan konten digital dan perangkat PSB.

Pentingnya upaya peningkatan kompetensi melalui pelatihan bagi penyelenggara PSB tersebut sesuai dengan hasil peneleitian Ramdani (2017) Kebutuhan terkait penyelenggaraan pelatihan atau kursus, bukan lagi hanya pelatihan atau kursus secara tatap muka, namun lebih kepada pelatihan atau kursus yang dapat diikuti secara fleksibel dan sesuai dengan kebutuhan serta gaya belajar. Beberapa rekomendasi materi pelatihan sesuai kebutuhan sekolah penerima bantuan perangkat PSB sebagai berikut: Bimtek pemanfaatan perangkat PSB dan pengelolaan PSB; Pelatihan penggunaan/pemanfaatan konten PSB; Pelatihan Strategi Pembelajarn Inovatif yang memanfaatkan konten digital PSB; Pelatihan pembuatan dan pengembangan konten materi PSB; Pelatihan Pembuatan video pembelajaran (Video interaktif dan video animasi pembelajaran); Pelatihan penyelenggaraan e-learning, Pelatihan pemanfaatan TIK dengan aplikasi terbaru dalam pembelajaran; Pelatihan pembuatan media pembelajaran berbasis TIK (Power point, pembuatan tes/kuis online, media web interaktif; Pelatihan aplikasi media pembelajaran terkini; Pelatihan membuat konten dan menyusun materi ajar yg menarik digital based; Workshop khusus seputar rumah belajar dan pemanfaatan semua fitur-fiturnya; Pelatihan pembuatan aplikasi pembelajaran non internet (luring). Data kebutuhan pelatihan bagi sekolah penerima bantuan perangkat PSB tersebut dapat dijadikan bahan pertimbangan dalam peningkatan kulaitas penyelenggaraan PSB di sekolah khususnya dalam pemanfaatan konten digtal PSB.

Kendala berikutnya terkait aspek aplikasi dan konten digital PSB. Beberapa kendala yang disampaikan oleh responden meliputi: Jumlah konten digital PSB yang terbatas dan belum lengkap untuk semua materi, ada beberapa konten video yang tidak dapat dibuka, sosialisasi pemanfaatan konten sumber digital PSB yang belum maksimal, aplikasi tidak lengkap, lemot masuk ke aplikasi. Untuk mengatasi kendala tersebut perlu diupayakan oleh tim pengelola aplikasi PSB, diantaranya: Meningkatkan kualitas dan performa aplikasi PSB. Ini penting karena akan sangat berpengaruh pada minat, motivasi dan daya Tarik penyelenggara PSB (guru, siswa, tenaga kependidikan di sekolah) dalam memanfaatkan aplikasi dan konten PSB. Upaya lainnya yang dapat direkomendasikan adalah: Meningkatkan jumlah dan kelengkapan konten PSB sesuai kebutuhan sekolah PSB; Memperbaiki kembali konten yang terkendala untuk di buka; Meningkatkan upaya partisipasi guru dan masyarakat untuk melengkapi materi; Melaksanakan Bimtek baik secara tatap muka maupun daring bagi SDM pengelola PSB (baik guru, pengelola TIK, perpustakaan dan sebagainya) sesuai identifikasi kebutuhan Bimtek dari sekolah PSB; Serta 
melakukan pendampingan bagi sekolah PSB yang akan melakukan perbaikan perangkat PSB yang terkendala/tidak berfungsi.

Kendala lainnya yaitu kurang maksimalnya dukungan kebijakan sekolah. Dalam hal ini dapat direkomendasikan beberapa upaya solusi, diantaranya: Meningkatkan dukungan kebijakan sekolah terkait ketersediaan sarpras TIK di sekolah; Dukungan kebijakan kepala sekolah dalam pemanfaatan konten digital PSB bagi guru dan siswa; Kebijakan untuk memotivasi guru agar lebih berinovasi dan berkreasi dalam pemanfaatan konten digital PSB, misalnya dengan memberikan rewards dan sebagainya; Serta Meningkatkan upaya pelibatan partisipasi masyarakat dalam penyediaan sarpras TIK dan pemanfaatan konten PSB. Pentingnya dukungan dari aspek kebijakan sekolah ini sesuai dengan pendapat Lestari (2015) yang menyatakan bahwa salah satu solusi dari kendala pemanfatan TIK adalah adanya dukungan kebijakan, tidak hanya dari pemerintah pusat, pemerintah daerah, instansi swasta tetapi juga dari kepala sekolah (Lestari, 2015). Sutrisno menyatakan bahwa kebijakan tersebut dapat dimaknai sebagai pemberian otonomi yang seluas-luasnya kepada sekolah dalam mengelola sekolah, termasuk di dalamnya berinovasi dalam pengembangan kurikulum dan model-model pembelajaran.

\section{SIMPULAN DAN SARAN Simpulan}

Pemanfaatan Konten digital PSB saat ini menjadi hal yang penting, terutama untuk mendukung penerapan pembelajaran bagi siswa generasi milenial (generasi Z). Bentuk pemanfaatan bantuan konten digital PSB di sekolah penerima bantuan perangkat PSB beragam diantaranya: Mayoritas guru (63\%) menyajikan di depan kelas dengan menggunakan projector. Sebagian guru (21\%) memanfaatkan Konten digital PSB sebagai sumber belajar mandiri bagi siswa. Siswa ditugaskan secara sendiri-sendiri ataupun berkelompok memanfaatkan konten digital sumber belajar di ruang kelas maupun perpustakaan. Sebagian yang lain yaitu sebanyak $11 \%$ guru memanfaatkan Konten digital PSB secara terjadwal dan dilakukan di ruang PSB di masing-masing sekolah. Dari sisi bentuk pemanfaatan dalam pembelajaran di kelas, guru paling banyak memanfaatkan Konten digital PSB dengan cara menyajikan di depan kelas menggunakan projector dengan metode ceramah, sebagian kecil yg lain sudah mengintegrasikan dengan model pembelajarn lain, Dari sisi kecenderungan jenis konten, siswa dan guru mayoritas (45\%) lebih menyukai jenis konten video pembelajaran.

Pemanfaatan Konten digital PSB oleh guru, siswa dan sekolah dimasingmasing sekolah PSB memiliki kendala yang berbeda-beda, diantaranya: Adanya keterbatasan sarana prasarana TIK tidak sebanding dengan jumlah siswa, sehingga sedikit siswa yg dapat memanfaatkan, Ruang PSB yang terlalu panas, dan kendala jaringan internet karena lokasi sekolah ada yang di pegunungan dan sebagainya. Kendala lainnya: Kurangnya kemampuan TIK guru; Kurangnya penguasaan guru tentang cara penggunaan konten dan aplikasi PSB; Minimnya dukungan terhadap guru penggerak; Jumlah konten digital PSB yang terbatas dan belum lengkap untuk semua materi; Ada beberapa konten video yang tidak dapat dibuka; Sosialisasi pemanfaatan konten sumber digital PSB yang belum maksimal; Aplikasi tidak 
lengkap; lemot masuk ke aplikasi; dan kurang maksimalnya dukungan kebijakan sekolah.

Ketersediaan guru penggerak cukup memadai, dimana 31\% sekolah yang memiliki guru lebih dari 5 orang guru yang mampu membuat konten bahan belajar digital mandiri, $53 \%$ sekolah memiliki kurang dari 5 guru yang mampu membuat bahan belajar digital mandiri. Sedangkan $16 \%$ sekolah tidak memiliki guru yang mampu membuat konten pembelajaran mandiri.

Beberapa rekomendasi peningkatan kualitas pemanfaatan konten digital PSB dan perangkat bantuan PSB, dapat diupayakan dari 4 aspek yaitu peningkatan ketersediaan sarana prasarana TIK, peningkatan kualitas SDM pengelola PSB, peningkatan kualitas aplikasi dan kuantitas konten digital PSB, serta peningkatan kualitas dukungan kebijakan.

\section{Saran}

Secara praktis, bagi tim aplikasi PSB perlu meningkatkan kualitas aplikasi dan kuantitas konten PSB digital, terutama konten-konten video pembelajaran yang materinya belum tersedia. Pemanfaatan konten PSB digital dan perangkat TIK PSB perlu terus ditingkatkan baik dari sisi kualitas bentuk dan strategi pemanfaatan agar lebih efektif. Bagi para pengambil kebijakan pendidikan, sekolah, dan guru hasil penelitian ini dapat dijadikan pertimbangan dalam meningkatkan kualitas pemanfaatan bantuan konten digital PSB dan perangkat TIK untuk mendukung peningkatan kualitas pembelajaran di sekolah PSB termasuk proses belajar dari rumah seperti pada saat situasi darurat pandemi covid-19 dengan memanfaatkan bantuan perangkat TIK dan konten digital PSB. Secara akademisi, hasil penelitian ini dapat dijadikan referensi dan kajian awal bagi penelitian-penelitian berikutnya yang menggali strategi pemanfaatan konten digital PSB dan pengendalian tindaklanjut pemanfaatan perangkat bantuan PSB dalam pembelajaran di sekolah/instasi penyelenggara PSB.

\section{REFERENSI}

Absher, K. \& Amidjaya, M.R. (2008). Teaching library instruction to the millennial generation. Dalam http://www.vla.org/Presentations/VLA_presentation draft072208.

Anwas, E Oos M; Irvana Steviano, Warsihna, Jaka. (2018). The use of internet content with interest in learning english on high schools students, The Turkish online Journal of Education Technology, p 832-836. http://www.tojet.net/special/2018_12_3.pdf, diakses tanggal 20 April 2020.

Asy'ari \& Zulkarnain, M.R. (2019). Eksperimentasi pembelajaran berbasis TIK menggunakan metode discovery learning dengan peer assessment di Kelas VIII SMP NEGERI 17 BANJARMASIN. LENTERA Jurnal IImiah Kependidikan, Vol. 14 No. 2, 16-26

Ayunda. (2020). Rumah belajar kemendikbud buka kelas online SD hingga SMK, https:/www.kompas.com/edu/read/2020/03/31/155703371/rumah-belajarkemendikbud-buka-kelas-online-sd-hingga-smk-ini-jadwalnya, diakses tanggal 2 April 2020. 
Destiana, B. (2014). Faktor determinan pemanfaatan TIK dan pengaruhnya terhadap kinerja guru SMK di Kabupaten Gunung Kidul. Jurnal Pendidikan Vokasi, Vol 4, Nomor 3, November, 285-299.

Filoza, A. dkk. (2019). Pemanfaatan media portal rumah belajar terhadap kemampuan berpikir kreatif siswa di SMP Negeri 3 Bengkulu Tengah. Prosiding Seminar Nasional Sains dan Entrepreneurshp, Volume VI Nomor 1, 1-9

Hevria, S. (2019). Constructivist learning model using Portal Rumah Belajar for primary school student. In International Conference on Education Technology (ICoET 2019). Atlantis Press.

https://belajar.kemdikbud.go.id/, diakses 18 Juni 2020.

Kusnandar. (2018). Inovasi pembelajaran berbasis TIK di sekolah 3T Provinsi Papua dan Papua Barat melalui pendampingan jarak jauh. Jurnal Kwangsan, Vol 6 No. 2, 19-20.

Kemendikbud. (2020). Surat edaran menteri pendidikan dan kebudayaan 36962/MPK.A/HK/2020 tanggal 14 Maret 2020 tentang pemberlakuan pembelajaran secara daring dari rumah bagi siswa dan mahasiswa.

Lestari, S. (2015). Faktor-faktor yang mempengaruhi pemanfaatan TIK oleh guru. Kwangsan, Vol. 3, No. 2, Edisi Desember, 121-134.

Martiningsih, R. (2013). Peningkatan prestasi belajar himpunan melalui penggunaan portal rumah belajar. Jurnal Teknodik, Vol. 17 Nomor 1, 3445.

Nurabadi, A. (2014). Ketersediaan dan pemanfaatan perangkat Teknologi Informasi (TI) dalam peningkatan mutu pembelajaran. Manajemen Pendidikan, Volume 24, Nomor 3, Maret, 221-227.

Rahmadi, Imam F. (2017). Mengembangkan Pusat Sumber Belajar di perguruan tinggi berdasarkan masalah dan kebutuhan terbaru. Jurnal PERSPEKTIF IImu Pendidikan, Vol. 31 No. 2 Oktober 2017.

Susilawati, E. (2019). Penerapan model pembelajaran inovatif yang memanfaatkan portal rumah belajar di SMP Pesat Bogor. Jurnal Teknodik, Vol. 23 Nomor $1,42-54$

Stufflebeam, D. L., \& Coryn, C. L. S. (2014). Evaluation theory, models, \& applications. San Francisco: Jossey-Bass. 